\title{
SULPHUR IN PROTEIN BODIES.
}

\author{
BY THOMAE B. OSBORNE. \\ Received seitemier 28 , I901.
}

I. HISTORICAI.

$K \begin{gathered}\mathrm{RUGGR} \text { ' has pointed out that the "sulphur content of } \\ \text { legumin, casein, fibrin and ovalbumin are to each other as }\end{gathered}$ $4: 8: 12: 16$, from which one can conclude that the number of sulphur atoms in them are as $\mathrm{I}_{n}: 2_{n}: 3_{n}$ " * * * "Leaving out of consideration the unknown molecular weight and, instead, taking into account the number of sulphur atoms, an equally great molecular weight may be assumed for all proteins. A comparison of this equally great atomic complex is possible, in respect to sulphur, because the proportion of the other elements in these bodies varies so little that it has no influence on the sulphur content."

Some time ago, before I was aware of Krüger's suggestions, I reached the same conclusion by a different line of reasoning. I pointed out that the molecular weight of those proteins which contain but 0.4 per cent. of sulphur must be at least 15,000 if there are two atoms of sulphur in their molecules and that similar molecular weights are obtained for a large number of the more carefully analyzed proteins, if their simplest empirical formulas, calculated on the basis of a single aton of sulphur, are multiplied by such a whole number as to give molecular weights nearest to i 5,000 .

The results thus obtained all fall so near to one another as to strongly suggest that all these bodies have similar molecular weights not far from ( I 5,000$)_{n}$.

The fact that the proteins all react with very small quantities of acids and alkalies and closely resemble one another in many of their physical characters, also indicates that they have similar high molecular weights. Further, the oxyhemoglobins from horse and dog blood must contain at least one molecule of protein, and as these have been shown by Zinoffsky ${ }^{3}$ and Jaquet to contain, respectively, 2 and 3 atoms of sulphur to 1 of iron (see page $16 \mathrm{I}$ ), the protein contained in them cannot have a

i Krüger: Pfüger's Archit., 43, 24.4.

is This Journal, 21, 486.

: Zischr physiol. Chem., 10, 16.

4 Ibid., 12, 284, and 14, 289 . 
molecular weight very far from 15,000, or a multiple of this. Furthermore, Sabanieff, ${ }^{1}$ in studying the lowering of the freezingpoint caused by colloid substances, found that those colloids, of which the molecular weight was known, depressed the freezingpoint to nearly the calculated extent and that the depression of the freezing-point caused by purified ovalbumin indicated a molecular weight of about 15,000 , a result which shows that the molecular weight of this substance is, at least, much higher than that corresponding to three atoms of sulphur.

In view of these considerations it seemed important to determine, as accurately as possible, the total sulphur in a considerable number of different proteins, in order to learn whether this formed a perfectly definite constituent of these substances and to also determine whether the fraction of this sulphur, converted into sulphide by heating with strong alkaline solutions, corresponded to a definite number of the atoms in the formulas calculated according to the method above described.

Fleitmann ${ }^{2}$ long ago showed that a part only of the sulphur of proteins was removed by heating with caustic alkali. Danielew$\mathrm{ski}^{3}$ confirmed Fleitmann's observations and later ${ }^{4}$ called attention to their importance and to the fact that they had apparently been disregarded by all those writers who had attempted to give formulas for the protein bodies, since these formulas were all constructed on the basis of a single sulphur atom.

Kriiger $^{5}$ determined the proportion of sulphur thus detached from ovalbumin and from fibrin and discussed at length the possible ways in which this sulphur could be united within the atomic complex which was split off and also the way in which the remaining sulphur could be united within the protein molecule. He also gave a table showing the structural formulas of various well-known sulphur compounds and, as far as possible, the behavior of these toward alkaline lead solutions.

Suter ${ }^{6}$ studied the behavior of several proteins when treated with hot alkaline lead solutions, and noted, as did Kriiger before him, the similarity of their behavior to that of cystin under the same conditions.

\footnotetext{
1 Chem. Centrbl., 10, $189 \mathrm{r}$.

2 Fleitmann : Ann. Chem. (Liebig), 61, 121, and 66, 380 (1847).

3 Danielewski : Zischr. Chem., Ia, \&I (1869).

4 Danielewski : Ztschr. physiol. Chem., 7, 443 (1883).

6riiger: Pfliger's Archiv., 43, 244 (1888).

- Suter : Zlschr. physiol. Chem., 20,564 (1895).
} 
Schulz' reviewed the work of the preceding investigators and attributed the lack of agreement between their quantitative results to a partial oxidation of the sulphide during the long heating required for its complete separation. This he attempted to obviate by adding metallic zinc to the soda solution. After satisfactorily testing this method with sodium thiosulphate, sulphourea, and thioacetic acid, he applied it to several proteins.

Since the work to be described in this paper was completed, K. A. H. Moerner ${ }^{2}$ has isolated cystin from the decomposition products of horn, hair, egg membrane, and serum albumin and further found that in the solutious freed from cystin another sulphur-containing body was present which yielded lead sulphide on treatment with hot alkaline lead solutions. This latter body, however, he did not identify. Embden has independently confirmed Moerner's observations, but considers cystein to be the primary decomposition product of serum and egg albumin and of edestin, and that cystin is a secondary product derived from cystein.

Since Schulz's method appears to yield satisfactory results, I have used it to determine the amount of loosely bound sulphur in a number of the protein substances which have been prepared and studied during the past few years in this laboratory and have compared the results with those obtained by heating the proteins under pressure with strong alkaline solutions at various temperatures. I have also carefully determined the total sulphur which these proteins contain, and give the amount found in each, in the following pages.

\section{ANALYTICAL METHODS.}

\section{a. Determination of Total Sulphur.}

About Io grams of sodium peroxide were converted into hydroxidet in a nickel crucible by adding a little water and boiling over an alcohol lamp until the excess of water was expelled. From I to 2 grams of the protein were then stirred into the slightly cooled hydroxide and oxidized by gradually raising the heat and adding small portions of sodium peroxide until the oxidation was

1 Schulz: Ztschr. physiol. Chem., 25, 16 (18g8).

2 Moerner: Ibid., 28, 595 (1899); also Proced. 13th Inter. Con. Med. Sec d.physiol., etc., p. I5, Paris, igoo.

3 Embden: Zischr, physiol. Chem., 32, 94 (1901).

4 I have found commercial sodium peroxide to be freer from sulphur than most preparations of so-called chemically pure sodium hydroxide made from the metal, and as the former is very much cheaper than the latter it is advantageous to use it as here described. 
complete. The fused mass was then dissolved in $400 \mathrm{cc}$. of water, its solution strongly acidified with hydrochloric acid, boiled until the excess of peroxide was destroyed and chlorive expelled, filtered through pure paper, made neutral with ammonia, and an excess of $4 \mathrm{cc}$. of concentrated hydrochloric acid added. From the boiling solution, sulphuric acid was precipitated by gradually adding a solution containing I gram of barium chloride. After standing over night on a steam table, the barium sulphate was filtered out, washed, ignited, and weighed.

\section{b. Determination of Loosely Bound Sulphur-Schulz's Method.}

Schulz's method consists in boiling, with a reflex condenser for several hours, I gram of the protein with $50 \mathrm{cc}$. of 30 per cent. sodium hydroxide solution containing I gram of metallic zinc and a little lead acetate. After slightly acidifying the solution with acetic acid, the lead sulphide formed is filtered out, washed with water, dried and fused, together with the filter-paper, with sodium hydroxide and potassium nitrate. In following Schulz's method, the lead sulphide was fused with sodium hydroxide and peroxide. The fusion is dissolved in water, its solution treated with carbonic acid (to remove lead), filtered, evaporated with an excess of hydrochloric acid, and sulphur determined as barium sulphate in the usual way.

\section{Pressure Method.}

From I to 5 grams of the protein were thoroughly mixed in a nickel crucible with $50 \mathrm{cc}$. of 50 per cent. sodium hydroxide solution containing some lead acetate, and the mixture heated in an autoclave for from two to seven hours, at temperatures of from $135^{\circ}$ to $165^{\circ} \mathrm{C}$, oxidation being prevented by absorbing the oxygen in the air within the autoclave with sodium pyrogallate. The lead sulphide, formed by thus heating, was filtered out, washed with water, dried, fused with sodium hydroxide and peroxide, and since the presence of silica was avoided by using nickel vessels, the sulphur was precipitated as barium sulphate directly from the acidified solutions of the fusion under the conditions used for determining total sulphur.

III. DETERMINATION . OF TOTAL AND LOOSELY BOUND SULPHUR IN VARIOUS PROTEINS.

Edestin.

This protein occurs in the seeds of hemp, flax, and squash, and 
also in the castor bean. As edestin separates readily in octahedral crystals when its saline solutions are dialyzed or cooled, relatively pure preparations of it can easily be made.

In order to learn with what degree of accuracy the total sulphur can be estimated and to establish the constancy of its sulphur content I have made the following determinations in twentyfour different crystallized preparations from the hemp seed, representing numerous fractional precipitations and different methods of preparation.

TABIF I.-PERChNTAGE OF TOTAL SULPHUR IN PRFPARATIONS OF EDESTIN FROM HEMP SEED.

\begin{tabular}{|c|c|c|c|c|c|c|}
\hline $\begin{array}{c}1 . \\
0.931\end{array}$ & $\begin{array}{c}\text { II. } \\
0.934\end{array}$ & $\begin{array}{l}\text { III. } \\
0.980\end{array}$ & $\begin{array}{l}\text { IV. } \\
0.895\end{array}$ & $\begin{array}{c}v \\
0.983\end{array}$ & $\begin{array}{c}11 . \\
0.960\end{array}$ & $\begin{array}{l}\text { VII. } \\
0.944\end{array}$ \\
\hline 0.942 & 0.924 & 0.938 & $\cdots$ & 0.963 & $\cdots$ & 0.941 \\
\hline 0.910 & 0.937 & $\ldots$ & $\ldots$ & $\ldots$ & $\ldots$ & $\ldots$ \\
\hline viII. & IX. & $\mathrm{x}$. & $\mathrm{X} 1$. & Sil. & XIII. & XIV. \\
\hline 0.990 & 0.990 & 0.997 & 0.943 & 0.874 & 0.864 & 0.900 \\
\hline 0.972 & $\ldots$ & 0.987 & .... & 0.900 & 0.866 & $\cdots$ \\
\hline 0.963 & $\ldots$ & $\cdots$ & $\cdots$ & $\cdots$ & $\ldots$ & $\cdots$ \\
\hline $\begin{array}{l}x y \\
0.9 \cap 2\end{array}$ & $\begin{array}{l}\text { NFI. } \\
0.893\end{array}$ & $\begin{array}{l}\text { XVII. } \\
0.934\end{array}$ & $\begin{array}{l}\text { Xvill. } \\
0.941\end{array}$ & $\begin{array}{l}\text { XIX. } \\
0.964\end{array}$ & $\begin{array}{c}x x \\
0.939\end{array}$ & $\begin{array}{l}\text { XXI. } \\
0.932\end{array}$ \\
\hline
\end{tabular}

The average of these figures is 0.936 per cent., the lowest being 0.066 per cent. below, the highest 0.06 per cent. above the average. The difference shown by these several preparations are not analytical, as the extreme figures are confirmed by closely agreeing duplicates.

It is evident from these results that it is possible to determine total sulphur with considerable accuracy, and it is also evident that these several preparations do not contain exactly the same amount of sulphur. I have previously shown ${ }^{1}$ that, owing to the natural acidity of the seed, crystallized edestin, as usually prepared, consists of a mixture of compounds of a basic protein molecule with acids, the nature of the acids depending upon the character and proportion of the salts present at the time the edestin was precipitated. Thus, when preparation XXIII, crystallized from ammonium sulphate solution, was suspended in water and neutralized to phenolphthalein by potassium hydroxide solution, the edestin remained undissolved and was separated by filtration from the water, in which was found a quantity of potassium sulphate corresponding to the amount of acid neutralized. This and another preparation similarly made contained the following amount of total sulphur :

1 This Journal, $24,39$. 


$$
\begin{array}{rc}
\text { XXII. } & \text { XXIII. } \\
\text { Per cent. } & \text { Per cent. } \\
\text { Sulphur }\left\{\begin{array}{l}
\text { I.I25 } \\
\text { I.IIO } \\
\text { I.IO3 }
\end{array}\right. & 1.084
\end{array}
$$

The acidity of these preparations to phenolphthalein was equal to an amount of sulphuric acid corresponding to the excess of sulphur in them above that of the average of I-XXI, all of which latter were made from sodium chloride solutions. These latter preparations, neutralized in the above described manner, yielded chiefly potassium chloride, but together with this chloride a small proportion of sulphate was always found. The differences in sulphur content of preparations I-XXI are thus explained. This excess of sulphur is therefore not to be regarded as belonging to the protein molecule. The amount of such sulphur is not great, since the total acidity of the preparations in no case exceeded I. $2 \mathrm{cc}$. of a decinormal solution per gram, which corresponds to sulphuric acid containing sulphur equivalent to 0 . I 9 per cent. of the protein.

Such an excess of sulphur is shown by preparations XXII and XXIII in which, as already stated, I found by actual analysis that the acidity was due to sulphuric acid.

In order to find the true amount of sulphur belonging to the edestin molecule I determined the total sulphur in a very pure and perfectly neutral preparation, made by several times recrystallizing edestin chloride, neutralizing its solution to phenolphthalein and again crystallizing. Two determinations of sulphur in this preparation gave 0.880 and 0.887 .

The average of these figures, 0.884 , unquestionably closely represents the total sulphur contained in the edestin molecule.

With this result several of the preceding agree closely (namely, IV, XII, XIII, XIV, XV, and XVI), all of which are either preparations consisting mostly of bichloride, soluble in pure water, which neutralization experiments have shown to yield extremely small amounts of potassium stuphate, or were preparations obtained from solutions made neutral to phenolphthalein. ${ }^{1}$

In order to learn with how much accuracy the loosely bound sulphur of edestin can be determined, the following large number of trials were made :

1 This Journal, $24,39$. 
TABLE II.-PERcentage OF LOOSELy BONND SULPHUR IN EDESTIN. One gram boiled with 30 per cent. $\mathrm{NaOH}, \mathrm{Zn}$, and $\mathrm{Pb}\left(\mathrm{C}_{2} \mathrm{H}_{3} \mathrm{O}_{2}\right)_{2}$.

\begin{tabular}{|c|c|c|c|c|c|c|}
\hline$\sqrt{\text { VII. }}$ & $\mathrm{XI}$. & \multicolumn{2}{|c|}{ XVI. } & XVII. & XXIII. & $\mathrm{xx}$. \\
\hline 0.282 & 0.376 & \multicolumn{2}{|c|}{0.355} & 0.309 & 0.297 & 0.348 \\
\hline 0.263 & 0.286 & \multicolumn{2}{|c|}{$0.32 \mathrm{I}$} & .303 & $\ldots$ & 0.302 \\
\hline$\ldots$ & 0.277 & \multicolumn{2}{|c|}{0.277} & $\cdots$ & $\ldots$ & $\ldots$ \\
\hline$\ldots$ & $\ldots$ & \multicolumn{2}{|c|}{$\therefore$} & .. & $\ldots$ & $\cdots$ \\
\hline \multirow{2}{*}{\multicolumn{7}{|c|}{ 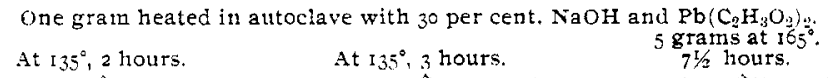 }} \\
\hline & & & & & & \\
\hline \multirow{3}{*}{$\begin{array}{l}\text { VIII. } \\
0.366 \\
0.297\end{array}$} & XXIII. & VIII, & XVI. & XXIII. & XXIV. & xxy. \\
\hline & 0.307 & 0.276 & 0.275 & $0.3 I 4$ & 0.339 & 0.363 \\
\hline & $\cdots$ & $\ldots$ & 0.265 & 0.300 & 0.344 & 0.347 \\
\hline$\ldots$ & $\ldots$ & $\ldots$ & . & 0.297 & $\ldots$ & 0.340 \\
\hline$\ldots$ & $\ldots$ & $\ldots$ & $\ldots$ & 0.240 & $\ldots$ & 0.337 \\
\hline
\end{tabular}

Of the determinations made with I gram of edestin, four are as high as those obtained with 5 grams at the higher temperature; the average of them all, however, is slightly but distinctly lower. As the results obtained with 5 grams of edestin at the higher temperature are probably the most accurate, their average, $\mathbf{0 . 3 4 6}$ per cent., may be considered to most closely represent the proportion of loosely bound sulphur, which can be obtained from edestin as lead stulphide.

\section{Excelsin}

Excelsin is obtained from the Brazil-nut (Bertholletia excelsa) by extraction with sodium chloride brine and is deposited in crystalline hexagonal plates by dialyzing its saline solutions. Five different preparations of excelsin contained the following amounts of sulphur :

$\begin{array}{ccccc}\text { TABLE III. - PERCENTAGE } & \text { OF TOTAL SULPHUR IN EXCELSIN. } \\ 1.1 & 2.1 & 3.1 & 4 .: & 5 .: \\ 1.06 & 1.12 & 1.07 & 1.083 & 1.109\end{array}$

The average of these figures, $\mathbf{1 . 0 8 8}$, closely represents the total sulphur of excelsin.

In making preparation 4, the oil-free meal was extracted with sodium chloride brine, the extract saturated with ammonium sulphate, the precipitate produced dissolved in water, its solution made neutral to litmus with sodium carbonate, and the excelsin precipitated in crystals by dialysis in water.

1 Osborne: Am. Chem. $J, 14,662$.

2 Preparations made recently. 
Preparation $\mathbf{5}$ was made by dialyzing a perfectly clear sodium chloride extract of the oil-free meal in running water, whereby the excelsin was deposited in uniformly large hexagonal plates.

As no more sulphur was found in preparation 4 than in 5 , it is evident that excelsin does not take up sulphuric acid from its saline solutions as readily as edestin does.

Excelsin is soluble in water when made neutral to phenolphthalein and therefore it has not been possible to identify the acids which are combined with it by the method applied to edestin.

The amount of loosely bound sulphur was determined in preparations 4 and 5 under the conditions given below.

Table IV.-Percentage of Loosely Bound Sulphur in Exceisin.

\begin{tabular}{|c|c|c|c|c|}
\hline \multirow{2}{*}{\multicolumn{2}{|c|}{$\begin{array}{c}\text { One gram boiled with } 30 \text { per cent. } \\
\text { NaOH, } \mathrm{Zn} \text {, and } \mathrm{Pb}\left(\mathrm{C}_{2} \mathrm{H}_{3} \mathrm{O}_{2}\right)_{2} \text {. } \\
71 / 2 \text { hours. }\end{array}$}} & \multirow[b]{3}{*}{4} & \multicolumn{2}{|c|}{$\begin{array}{l}\text { Heated in autoclave witb } \\
30 \text { per cent. NaOH. }\end{array}$} \\
\hline & & & \multirow{2}{*}{$\begin{array}{c}\text { One gram at } 135^{\circ} \\
2 \text { hours. } \\
5\end{array}$} & \multirow{2}{*}{$\begin{array}{l}\text { Five grams at } 165^{\circ} \\
4 \frac{1}{2} \text { hours. } \\
5\end{array}$} \\
\hline 4 & 5 & & & \\
\hline 0.339 & 0.347 & 0.294 & 0.293 & 0.350 \\
\hline 0.321 & 0.344 & $\ldots$ & $\ldots$ & $\ldots$ \\
\hline 0.289 & 0.297 & $\ldots$ & $\cdots$ & $\ldots$ \\
\hline 0.277 & 0.290 & $\cdots$ & $\ldots$ & $\cdots$ \\
\hline 0.257 & 0.284 & $\ldots$ & $\ldots$ & $\ldots$ \\
\hline$\ldots$ & $0.28 \mathrm{I}$ & $\cdots$ & $\ldots$ & $\ldots$ \\
\hline
\end{tabular}

The result obtained at $165^{\circ}$ agrees closely with the higher figures found by Schulz's method, and as experimental errors were diminished in this determination by employing a larger amount of substance, $\mathbf{0 . 3 5 0}$ per cent. may be taken as the proportion of loosely bound sulphur that can be obtained from excelsin.

\section{Legumin.}

Legumin, found in considerable quantity in the seeds of the pea, horse bean, vetch and lentil, is a protein substance having the properties of a globulin. It is not a nucleo-proteid, as stated by Hammarsten, since the many pure preparations, which I have made, were entirely free from phosphorus. ${ }^{3}$ The loosely bound sulphur was determined in carefully purified preparations, made according to the methods described in my papers last cited. Several closely agreeing new determinations of the total sulphur in these preparations showed them to contain the following proportion :

1 Osborne : Report of the Connecticut Agricultural Experiment Station for 1895, p. 262, and 1897 , p. 324; also This Journa1, 18, 583, and $\mathbf{2 0}, 348,362,393,406$, and 410 . 

TABI, V.-PERCENTAGE OF TOTAI, SULPHUR IN LEGUMIN.

$\begin{array}{lccc}\text { Pea. } & \text { I.entil. } & \text { Horse-bean. } & \text { Vetch. } \\ 0.37 \text { I } & 0.390 & 0.390 & 0.389\end{array}$

The percentage of loosely bound sulphur obtained from these preparations by different methods was as follows :

TABI, VI,-PERCENTAGF, OF LOOSELY BOUNI SUI,PHUR IN LEGUMIN.

\begin{tabular}{|c|c|c|}
\hline $\begin{array}{c}\text { One gram boiled with } \\
30 \text { percent. NaOH, } \mathrm{Zn} \text {, } \\
\text { and } \mathrm{Pb}\left(\mathrm{C}_{2} \mathrm{H}_{3} \mathrm{O}_{3}\right)_{2} \text {. } \\
7 / 2 \text { hours. }\end{array}$ & $\begin{array}{c}\text { One gram with } 30 \text { per } \\
\text { cent. NaOH and } \\
\left.\text { Ph( } \mathrm{C}_{2} \mathrm{H}_{3} \mathrm{O}_{0}\right)_{1} \text { at } 1.35^{\circ} \\
2 \text { hours. }\end{array}$ & $\begin{array}{c}\text { Five grams with } 30 \text { per } \\
\text { cent. } \mathrm{NaOH}_{2} \mathrm{Zn}, \text { and } \\
\left.\text { Ph( } \mathrm{C}_{2} \mathrm{H}_{3} \mathrm{O}_{2}\right)_{2} \text { at } 165^{\circ} . \\
5 \text { hours. }\end{array}$ \\
\hline Pea $\cdots \cdots \cdots\left\{\begin{array}{l}0 . \mathrm{I} 43 \\
0.143\end{array}\right.$ & $\ldots \ldots$ & . \\
\hline Horse-bean ... 0.193 & 0.164 & 0. I 86 \\
\hline I.entil ....... 0.193 & $\cdots$ & $\cdots$ \\
\hline Vetch $\ldots \ldots \ldots\left\{\begin{array}{l}0.159 \\
0.160\end{array}\right.$ & $\cdots$ & $0.15^{\circ}$ \\
\hline
\end{tabular}

The average of the figures for total sulphur is 0.385 per cent. and for the loosely bound sulphur 0.I66 per cent.

\section{Vignin.}

Under this name I described the chief protein of the cow pea and gave its sulphur content as 0.50 per cent.

Through an oversight, the correction for a small amount of sulphur contained in the reagents used at that time was omitted and consequently this figure for sulphur is a little too high. I have since repeated these determinations on all but one of the preparations described, and have obtained the following results:

\begin{tabular}{|c|c|c|c|c|c|c|}
\hline $\begin{array}{c}I \\
0.382\end{array}$ & $\begin{array}{c}2 \\
0.443\end{array}$ & $\begin{array}{c}3 \\
0.356\end{array}$ & $\begin{array}{c}4 \\
0.365\end{array}$ & $\begin{array}{c}6 \\
0.360\end{array}$ & $\begin{array}{c}8 \\
0.416\end{array}$ & $\stackrel{9}{0.417}$ \\
\hline & 0.439 & & & & & \\
\hline
\end{tabular}

The average of these figures is 0.391 .

Preparation 2 constituted the greater part of all the protein extracted from the seed, whereas 3,4 , and 6 , successively precipitated from the filtrate from 2, formed a relatively small part of the total protein matter. As 8 and 9, fractions of 2, contain nearly the same quantity of sulphur as 2 , the average of the figures given for these three preparations, 0.426 , may be taken as closely representing the total sulphur or vignin.

: Report of Connecticut Agricultural Experiment station for 1896, p. 380 ; also This Journa1, 19, 494. 
TABI, VIII.-PERCENTAGE OF LOOSELY BOUND SULPHUR IN VIGNIN.

One gram boiled with 30 per cent. NaOH,

$\mathrm{Zn}$, and $\mathrm{Pb}\left(\mathrm{C}_{2} \mathrm{H}_{3} \mathrm{O}_{2}\right)_{\text {. }}$.

$7 \frac{1}{2}$ houts.

0.210

0.213
One gram with 30 per cent. NaOH and $\mathrm{Pb}\left(\mathrm{C}_{2} \mathrm{H}_{3} \mathrm{O}_{2}\right)_{2}$ at $135^{\circ}$. 3 hours.

0.220 ....

The average of these figures is 0.214 per cent.

\section{Amandin.}

Amandin is the most abundant protein in the seeds of the almond and peach.

In a former paper ${ }^{1}$ I gave the total sulphur in five preparations of amandin as follows :

TABIE IX.-PERCENTAGE, OF TOTAI, SUlPHUR IN AMANDIN.

$\begin{array}{ccccc}1 & 2 & 3 & 4 & 5 \\ 0.39 & 0.44 & 0.48 & 0.45 & 0.48\end{array}$

A redetermination of sulphur in 3 , using 1.6688 grams, gave 0.429 per cent. Preparations 2, 3, and 4 were precipitated with ammonium sulphate; $\mathbf{I}$ and $\mathbf{5}$ were made without using this salt.

The recent determination of sulphur, which is probably the most accurate, shows that amandin contains about 0.429 per cent. of sulphur.

TABIE X.-PERCENTAGE OF LoOSEly Bound Sulphur in AMandin.

One gram boiled with 30 per cent. NaOH, $\mathrm{Zn}$, and $\mathrm{Pb}\left(\mathrm{C}_{2} \mathrm{H}_{3} \mathrm{O}_{2}\right)_{2}$ at $\mathrm{I}_{3} 5^{\circ}$.
2 hours
o. 180
0.172
0.165

Five grams with 30 per cent.

$\mathrm{NaOH}$ and $\left(\mathrm{PbC}_{2} \mathrm{H}_{3} \mathrm{O}_{2}\right)_{2}$ at $165^{\circ}$.

$$
\begin{gathered}
0.217 \\
\ldots \ldots \\
\ldots
\end{gathered}
$$

The result obtained at the higher temperature and with the larger amount of substance is doubtless the most correct of the above figures, so that 0.217 per cent. may be taken as the proportion of sulphur which can be obtained from amandin, as sulphide.

\section{Glycinin.}

The greater part of the protein matter of the soy bean is glycinin, a globulin described in a paper previously published. ${ }^{3}$ Careful redeterminations of sulphur in several of the preparations, described in the paper cited, showed that the figures there given were nearly correct; the average of the new determinations gave

1 Osborne and Campbell: Report of the Connecticut Agricultural Experiment Station for 1895 ; This Journal, $18,487$.

2 Osborne and Campbell : Report of the Connecticut Agricultural Experiment Station for 1897 ; also This Journal, 20, 419. 
0.700 per cent. of sulphur against the published figure, 0.72 per cent. The total sulphur in glycinin is therefore 0.710 per cent.

TABLE XI.-PERCENTAGE OF LOOSELY BOUND SULPHUR IN GLYCININ.

(One gram boiled with 30 per cent. $\mathrm{NaOH}$, $\mathrm{Zn}$, and $\mathrm{Pb}\left(\mathrm{C}_{2} \mathrm{H}_{3} \mathrm{O}_{2}\right)$

Preparation 2.... $\begin{aligned} & 0.32 \mathrm{I} \\ & 0.305 \\ & 0.274 \\ & 0.263 \\ & 0.286\end{aligned}$

Five grams with 30 per cent. $\mathrm{NaOH}$ and $\mathrm{Pb}\left(\mathrm{C}_{2} \mathrm{H}_{43} \mathrm{O}_{2}\right)_{2}$ at $\mathrm{I} 65^{\circ}$ 3 hotits. 0.317

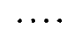

$\cdots$

$\cdots$

Since the result obtained with 5 grams of glycinin agrees closely with the higher figures obtained by boiling at the atmospheric pressure, we may safely assume that glycinin yields very nearly 0.320 per cent. of sulphur as sulphide.

\section{Gliadin.}

Gliadin, soluble in alcohol of $70-80$ per cent., is one of the most abundant proteins of the wheat kernel. In a paper on the protein constituents of this seed, ${ }^{1}$ the total sulphur of gliadin was given as I.I4 per cent.

This figure was the average found in a large number of preparations, all of which were not entirely pure. Careful redeterminations of sulphur in several of the purest of these preparations gave the following results :

Table XII.-Totai, Sulphur in Griadin.

$\begin{array}{ccccc}17 & 23 & 28 & 29 & 33 \\ 1.124 & 1.002 & 1.022 & 1.030 & 1.058 \\ 1.124 & \ldots & 1.005 & \ldots & 1.027\end{array}$

Excluding the figures given for $\mathbf{I 7}$, which for some reason contains more sulphur than the others, the average sulphur content of gliadin appears to be $\mathbf{I . 0 2 7}$ per cent.

The preparation of gliadin used in the following experiments consisted of a mixture of several of the purer products obtained in the former investigation and contained r.044 per cent. of sulphur.

TABLE XIII.-PERCENTAGE OF LOOSELY BOUND SULPHUR IN GI,IADIN.

\begin{tabular}{|c|c|c|}
\hline $\begin{array}{l}\text { One gram boiled with } \\
3^{\circ} \text { per cent. } \mathrm{NaOH}, \mathrm{Zn} \text {, } \\
\text { and } \mathrm{Pb}\left(\mathrm{C}_{2} \mathrm{H}_{8} \mathrm{O}_{2}\right)_{2} \text {. } \\
7_{1 / 2} / 2 \text { hours. }\end{array}$ & $\begin{array}{l}\text { One gram with } 30 \text { per } \\
\text { cent. } \mathrm{NaOH} \text { and } \\
\mathrm{Pb}\left(\mathrm{C}_{2} \mathrm{H}_{3} \mathrm{O}_{2}\right)_{2} \text { at } \mathrm{I}_{3}^{\circ} . \\
4 \text { hours. }\end{array}$ & $\begin{array}{c}\text { Five grams with } 30 \text { per } \\
\text { cent. } \mathrm{NaOH} \text { and } \\
\mathrm{Pb}\left(\mathrm{C}_{2} \mathrm{H}_{3} \mathrm{O}_{2}\right)_{2} \text { at }{ }^{\circ} 5^{\circ} \\
5 \text { hours. }\end{array}$ \\
\hline 0.627 & 0.635 & 0.624 \\
\hline 0.516 & $\ldots$ & $0.6 \mathrm{II}$ \\
\hline . & $\ldots$ & 0.600 \\
\hline
\end{tabular}

1 Osbortie and Voorhees: $A$ m. Chem. J., 15, 392. 
The average of these figures, excluding the lowest, is $0.6 \mathrm{rg}$, which doubtless nearly represents the percentage of loosely bound sulphur in gliadin.

\section{Hordein.}

Hordein, soluble in strong alcohol, occurs in quantity in the barley grain.

In ten different preparations, representing fractional precipitations of this substance, the average content of sulphur was 0.83 per cent. ${ }^{1}$ In a preparation recently made for the experiments here described, the total sulphur was 0.847 per cent.

TABLE XIV.-PERCENTAGe of LoOShiy BoUNd Sulphur in Hordein.

One gram boiled with 30 per cent. NaOH, $\mathrm{Zn}$, and $\mathrm{Pb}\left(\mathrm{C}_{2} \mathrm{H}_{3} \mathrm{O}_{2}\right)_{2}$.
$71 / 2$ hours. 0.348
One gram with 30 per cent. $\mathrm{NaOH}$ and $\mathrm{Pb}\left(\mathrm{C}_{2} \mathrm{H}_{8} \mathrm{O}_{2}\right)_{2}$

$$
\begin{gathered}
\text { at I } 35^{\circ} \text {. } \\
4 \text { hours. } \\
0.338
\end{gathered}
$$

Five grams with 30 per cent. NaOH and $\mathrm{Pb}\left(\mathrm{C}_{2} \mathrm{H}_{9} \mathrm{O}_{2}\right)_{2}$ at $165^{\circ}$. 3 hours.

0.358

The average of these figures gives 0.348 per cent. of loosely bound sulphur in hordein.

\section{Zein.}

Zein is the most abundant protein found in the maize kernel. It is especially characterized by its ready solubility in alcohol of 90 to 95 per cent., though in absolute alcohol it is wholly insoluble. In a former paper ${ }^{2}$ the average amount of total sulphur, in nine different preparations of zein, was given as 0.60 per cent.

TABLE XV.-PERCENTAGE OF LOOSELY BOUND SULPFUR IN ZEIN.

\section{One gram boiled with 3 per}

cent. NaOH, $Z n$, and

$\mathrm{Pb}\left(\mathrm{C}_{2} \mathrm{H}_{3} \mathrm{O}_{2}\right)_{2}$.

$71 / 2$ hours.

0.243

0.248
One gram with 30 per cent.

$\mathrm{NaOH}$ and $\mathrm{Pb}\left(\mathrm{C}_{2} \mathrm{H}_{3} \mathrm{O}_{2}\right)_{2}$

at $135^{\circ}$.

$0.16 I$

0.160
Five grams with 30 per cent. NaOH and $\mathrm{Pb}\left(\mathrm{C}_{2} \mathrm{H}_{3} \mathrm{O}_{2}\right)_{2}$ at $165^{\circ}$. $4 \frac{1}{2}$ hours.

0.212

The result obtained with five grams of zein at $165^{\circ}$ probably represents most nearly the amount of loosely bound sulphur yielded by zein, which may therefore be taken as 0.212 per cent.

\section{Phaseolin.}

In a former paper on the proteins of the kidney bean, ${ }^{3}$ I gave the ave rage amount of sulphur found in twenty-four different preparations of phaseolin as 0.56 per cent. Among these preparations

1 asborne : Report of the Connecticut Agricultura1 Experiment Station for 1894, p. 165; also This Journal, 17,539.

2 Chittenden and Osborne: Am. Chemt. J., 13,327, 385, and 14, 20.

8 Osborne: Report of the Connecticut Agricultural Experiment Station for 1893 : also This Jou. -1a1, 16, 633, 703 and 757 . 
was one consisting almost wholly of octahedral crystals in which duplicate determinations give 0.33 and 0.29 per cent. of sulphur. I have since prepared a large quantity of phaseolin by extracting the bean meal with io per cent. ammonium sulphate solution, precipitating the proteins by saturating the extract with the same salt, dissolving the precipitate in water, fittering the resulting solution and then dialyzing it for four days. The precipitate which first formed consisted of relatively large octahedral crystals, with which amorphous matter was afterwards deposited. This precipitate, AI, was filtered out, redissolved in ammonium sulphate solution and the filtered liquid dialyzed for four days, whereupon considerable precipitate, A2, separated, consisting of amorphous matter and octahedral crystals, some of which were large enough to be easily recognized by the naked eye. Several grams of these crystals, $\mathrm{A} a$, were separated by elutriation nearly free from amorphous matter and were found to contain 0.265 per cent. of sulphur. The solution filtered from this last dialysis precipitate yielded, after seven days' further dialysis, 58 grams of partly crystallized phaseolin, AI, which contained 0.328 per cent. of sulphur.

The filtrate from the first dialysis precipitate, AI, above described, after dialyzing for four days more, gave a large precipitate which, when redissolved and again precipitated by dialysis, yielded 67 grams of $A_{2}$, containing 0.356 per cent. of sulphur. By dialyzing the filtrate from the first precipitation of $\mathrm{A}_{2}$ for seven days longer, 22 grams of $A_{3}$ were obtained, which contained 0.417 per cent. of sulphur.

From these results and those of the earlier investigation, it appears that uncertainty still exists respecting the total sulphur of phaseolin, and until we can prepare this substance in a completely crystallized condition it is impossible to assign a precise value to its sulphur content.

TABle XVI.-PERCENTAGE of LOOSFly Bound SUlphuR iN PHASEOLiN.

\begin{tabular}{|c|c|}
\hline $\begin{array}{c}\text { One gram boiled with } 30 \text { per cent. } \\
\mathrm{NaOH}, \mathrm{Zn}_{1} \text { and } \mathrm{Pb}\left(\mathrm{C}_{2} \mathrm{H}_{3} \mathrm{O}_{2}\right)_{\%} \\
71 / 2 \text { hours. }\end{array}$ & $\begin{array}{c}\text { Five grams with } 30 \text { per cent. } \\
\text { NaOH and } \mathrm{Pb}\left(\mathrm{C}_{2} \mathrm{H}_{3} \mathrm{O}_{2}\right)_{2} \text { at } 165^{\circ} . \\
5 / 2 \text { hours. }\end{array}$ \\
\hline Preparation A I ... $\begin{array}{l}0.062 \\
0.079\end{array}$ & 0.063 \\
\hline Preparation A2 ... $\left\{\begin{array}{l}0.092 \\
0.076\end{array}\right.$ & $\cdots$ \\
\hline
\end{tabular}

The average of these figures is $\mathbf{0 . 0 7 2}$ per cent. 


\section{Vicilin.}

Vicilin is a globulin, found by the writer in the seeds of the pea, lentil, and horse bean, and described in papers published some time ago.' This substance, like phaseolin, presents an uncertainty respecting its total sulphur. Twenty-one preparations, whose complete analyses agreed closely in other respects, contained from 0.23 to 0.08 per cent. of sulphur. This difference was not analytical, as the extreme figures were confirmed by duplicate determinations; thus for preparation 62, I found 0.08 and 0.07 per cent., for 840.10 and 0.09 , and for 940.103 and 0.099 per cent., while for 55 I obtained $0.2 \mathrm{I}$ and 0.24 , and for $580.2 \mathrm{I}$ and 0.20 per cent. of sulphur.

This difference among the preparations might be due to a mixture of a sulphur-free protein and legumin, with which vicilin is associated in these seeds, but this seems hardly possible, since the preparations with 0.20 per cent. of sulphur would, in this case, contain $5 \circ$ per cent., and those with 0.10 per cent. of sulphur 25 per cent. of legumin, which, if present in such different proportions, would probably cause greater differences in composition than were shown by the successive fractional precipitations of vicilin, which apart from sulphur showed no notable differences in composition. Further, the very limited solubility of legumin in the dilute salt solutions, from which vicilin was obtained, makes it highly improbable that we have here a mixture of a sulphur-free protein with a very notable amount of legumin.

The actual sulphur content of vicilin is a matter of importance in relation to the molecular weight of this substance, since, if but one atom of sulphur is contained in its molecule and sulphur is present in all the molecules of those preparations which contained but 0.10 per cent. of sulphur, the molecular weight of vicilin must be approximately 30,000 and if the molecules contain two atoms of sulphur, 60,000 . It is possible, however, that the sulphur-containing complex in vicilin is so loosely combined that it is easily detached, so that the preparations become mixtures of molecules containing sulphur and those containing none. This latter possibility seems probable since $I .5^{8}$ grams of 94 , from the horse bean, in which two determinations gave 0.103 and 0.099 per cent. of total sulphur, when heated for three hours with 30

1 Osborne and Campell : Report of the Connecticut Agricultural Experiment Station for:1897; also this Journal, $20,348,362,393$, and 4 Io. 
per cent. sodium hydroxide and lead acetate at a temperature of $165^{\circ}$, yielded but a trace of lead sulphide. Unfortunately no more of any other preparation containing so little sulphtur was available, with which this observation could be confirmed.

The amount of loosely bound sulphur found in vicilin was determined in a preparation from the pea which contained 0.220 per cent. of total sulphur.

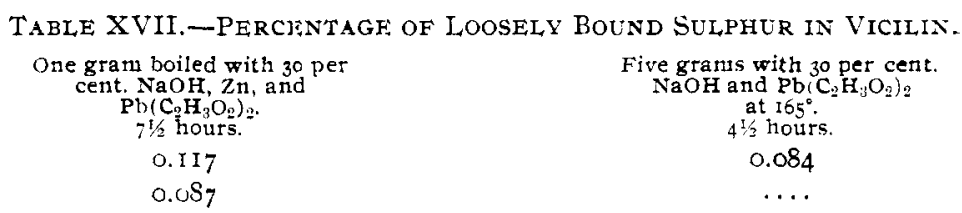

Five grams of another preparation, 93, which contained 0.150 per cent. of total sulphur, when treated for four and one-half hours at $165^{\circ}$ with 30 per cent. sodium hydroxide and lead acetate, yielded $0.05^{8}$ per cent. of sulphur as sulphide.

From these results it seems possible that from vicilin, sulphur is more easily detached than from the other proteins.

\section{Conglutin.}

An extended study of conglutin has shown ${ }^{1}$ that from the seeds of the yellow lupin, by extracting with brine and precipitating by dialysis or by abundant dilution, preparations are obtained which contain about 0.9 per cent. of sulphur, while from the blue lupin preparations similarly obtained contain from 0.40 to 0.50 per cent. By fractional precipitation the crude conglutin from the yellow lupin can be separated into fractions, which have a pretty constant sulphur content, the one containing from 0.5 to 0.6 per cent., the other I.4 to I.5 per cent. The preparations with the larger quantity of sulphur contain about I.5 per cent. less carbon than those with the smaller and also a little more nitrogen. Fractional precipitation of crude conglutin from the blue lupin gives products differing little in composition though the more soluble contain somewhat less carbon and nitrogen and a very little more sulphur. In the less soluble fractions, which have otherwise nearly the same composition and properties, somewhat different amounts of sulphur were found ; thus, four fractions contained : $37,0.32 ; 39$, $0.24 ; 42,0.38$; and $44,0.33$ per cent. Although these differ-

1 Osborne and Campbell: Report of the Conuecticut Agricultural Experiment Station for 1896, p. 288 ; also This Journal, I8, 609 ; also Rithausen: J; prakl. Chem., 103, 78; Ibid., 11. $f, 24,222$, and 26, 422, and Eiweisskörper, etc., Bonn, 1872 . 
ences are slight they were shown to be actual by recently repeated determinations, using large quantities of substance.

The average composition of the least soluble fractions from the blue and yellow lupin is very nearly the same with the exception of sulphur, about 0.2 per cent. more of which is found in the latter.

The preparations obtained from these two seeds appear to be either compounds of one and the same protein body, conglutin, with more or less of some substance rich in sulphur, which is present in greater amount in the yellow than in the blue lupin, or mixtures of various proportions of similar proteins which contain very different amounts of sulphur. This latter supposition appears the more probable because about the same proportion of loosely bound sulphur was found in all the preparations, whether they contained 0.3 per cent. or $\mathrm{I} .4$ per cent. of total sulphur. It is improbable that a sulphur-containing substance is combined with the protein from which the same proportion of lead sulphide can be obtained as from the protein itself.

The total sulphur in the different preparations of conglutin used in the following experiments was:

Table XVIII.-Percentage of Total Sulphur in Different Fractional Precipitates of Conglutin.

$\overbrace{\begin{array}{c}\text { I } \\ 0.393\end{array} \quad \begin{array}{c}\text { II } \\ 0.359\end{array}}^{\text {Blue lupin. }}$

\begin{tabular}{|c|c|c|}
\hline III & IV & $\mathrm{v}$ \\
\hline 0.530 & 0.954 & I. $37^{8}$ \\
\hline
\end{tabular}

ABJE XIX.-PERceNTAGE OF LOOSEI,Y BOUND SUIPHUR IN THE ABOVE PREPaRations.

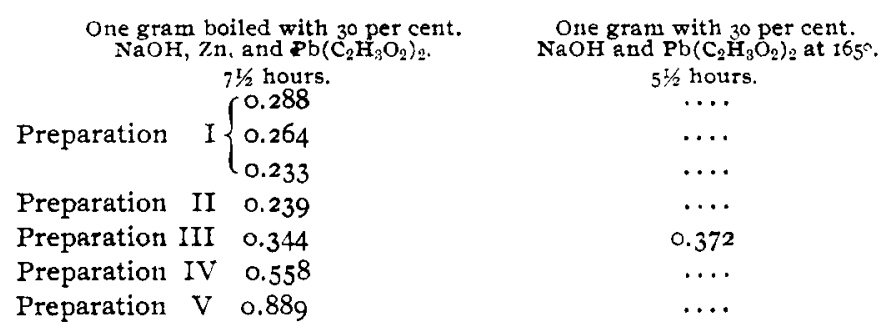

These figures show that very nearly two-thirds of the sulphur of each of these preparations was obtained as lead sulphide, the amounts found falling between 59 to 70 per cent. of the total sulphur. 


\section{Oxylhemoglobin from Dog's Blood.}

Hoppe-Seyler found 0.39 per cent. of sulphur in oxyhemoglobin from dog's blood. Jaquet found 0.5417 and 0.5414 per cent. of sulphur in this substance and later ${ }^{3} 0.5688$ and 0.5665 . Jaquet's determinations were made with very great care and a large amount of carefully recrystallized substance ris used for each determination.

In two carefully prepared and repeatedly recrystallized preparations of this substance, ${ }^{4}$ I have found 0.600 and 0.567 per cent,, and in another preparation once recrystallized 0.546 per cent. of total sulphur.

The average of Jaquet's determinations and my own gives 0.5618 per cent. of total sulphur in dog's blood oxyhemoglobin.

Six grams of oxyhemoglobin, once recrystallized, when heated for seven and one-half hours at $165^{\circ}$ with 30 per cent. sodium hydroxide and lead acetate, gave 0.342 per cent. of loosely bound sulphur, and five grams of another preparation which had been recrystallized several times gave, under the same conditions, 0.328 per cent. The arerage of these figures, 0.335 per cent., doubtless closely represents the proportion of loosely bound sulphur contained in this substance.

\section{Ovalbumin.}

In an investigation of the protein constituents of the egg white, the results of which have been recently published, "I determined, with special care, the total amount of sulphur contained in ovalbumin. In ten different preparations of repeatedly recrystallized ovalbumin I found the following quantities:

TABI, XX, - PERCENTAGF OF TOTAI, SULPRUR IN OVALBUMIN.

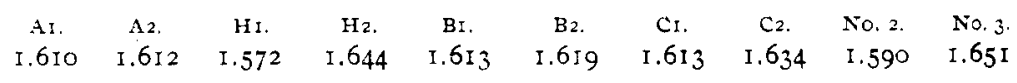

The details of the methods employed for the production of these preparations and the evidence of their purity may be found in the paper cited under the designations given in the above table.

1 Hoppe-Seyler: Med. Cntersuch, r868, p. 370.

2 Jaquet: Ztschr. physiol. Chem., 12, 285.

3 Ibid., 14, 289.

4 I am indebted to the kindness of Prof: L. B. Mendel for an abundant supply of this oxyhemoglobin from which the preparations used in these experiments were made.

$s$ Report of the Connecticut Agricultural Experiment Station for 1899 ; also This Journal, 22, 422. 
These figures agree well with those given by several other investigators, namely :

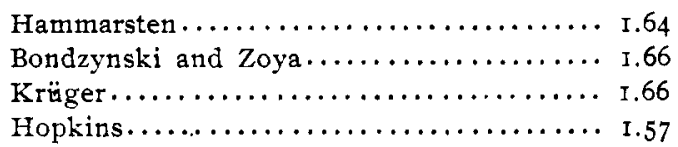

Taking the average of my figures as nearly correct, the total stlphur in ovalbumin may be given as 1.616 per cent.

Table XXI.-Percentage of Loosely Bound Sulphur in Ovalbumin.

One gram boiled with 30
per cent. NaOH, $\mathrm{Zn}$ and
$\mathrm{Pb}\left(\mathrm{C}_{2} \mathrm{H}_{3} \mathrm{O}_{2}\right)_{2}$.
$7 \mathrm{~L} / 2$ hours.
0.523
$0.5 \mathrm{II}$
0.504
$0.47 \mathrm{I}$
0.455
0.425

One gram with 30 per
cent. $\mathrm{NaOH}_{2}$ and
$\mathrm{Pb}\left(\mathrm{C}_{2} \mathrm{H}_{3} \mathrm{O}_{2}\right)_{2}$ at $135^{\circ}$.
2 hours.
0.523
0.518
0.505
0.459
0.441

Five grams with zo per

cent. NaOH and

$\mathrm{Pb}\left(\mathrm{C}_{2} \mathrm{H}_{3} \mathrm{O}_{2}\right)_{2}$ at $\mathrm{I} 65^{\circ}$

$4 \mathrm{~L} / 2$ hours.

0.49 I

$$
2 \text { hours. }
$$$$
\text { .... }
$$

The result obtained with five grams at $165^{\circ}$ agrees very closely with the average of the others and is also in accord with the results obtained by $\mathrm{Krüger}^{1}$, Malerba ${ }^{2}$ and Schulz ${ }^{3}$, who found, respectively, $0.44,0.49$ and 0.49 per cent. of loosely bound sulphur in ovalbumin. The amount of sulphur that can be obtained as sulphide by treating ovalbumin with hot alkali is therefore $0.49 \mathrm{I}$ per cent.

\section{Ovovitellin.}

The substance used in these experiments was preparation 2 described in a former paper on the proteins of the egg yolk ${ }^{4}$.

The total sulphur found in four fractional precipitations of this substance was the following:

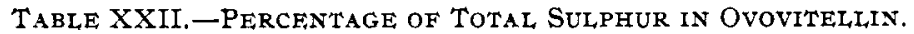

$\begin{array}{cccc}2 & 3 & \mathbf{3} & \mathbf{5} \\ 1.046 & 1.000 & 1.047 & 1.026\end{array}$

The average of these figures gives 1.028 per cent. of total sulphur. The amount of loosely bound sulphur was found to be the following :

1 Pflüger's Archiv., 43, 244.

2 Rendic della R. Accad. delle Scieuze di Sapoli, fasc. 3-5, 1894.

Lor. cil.

4 Osborne and Campbell: Report Connecticut Agricultural Experiment Station for 1899 ; also This Journal, 22, 413 . 
TABle XXIII.-Percentage of LoOsely bound Sutphur in Oro-

One gram with 30 per cent.

$\mathrm{NaOH}$ and $\mathrm{Pb}\left(\mathrm{C}_{2} \mathrm{H}_{3} \mathrm{O}_{2}\right)_{2}$ at ${ }_{3} 5^{-}$. 2 hours.

0.367

0.320 VTREITIN.

Five grams with 30 per cent. $\mathrm{NaOH}$ and $\mathrm{Pb}\left(\mathrm{C}_{2} \mathrm{H}_{2} \mathrm{O}_{2}\right)_{2}$ at 165 .
$51 / 2$ hours.

0.357

The average of the higher of these figures, 0.362 , probably closely represents the amount of sulphur split from ovovitellin by alkali.

\section{Casein from Cow's Milk.}

Chittenden and Painter ${ }^{1}$ have made an extensive study of the composition of casein prepared in different ways and have confirmed Hammarsten's many analyses of this substance. Hammarsten" found by extensive and painstaking experiments that the total sulphur of casein was 0.78 per cent., Chittenden and Painter that it was 0.82 per cent. The average of these figures, 0.80 per cent., may therefore be taken for the total sulphur of casein.

The loosely bound sulphur was determined in a preparation of casein made from milk from which the fat had been thoroughly separated by centrifugation immediately after it had been drawn from the cow. Just enough hydrochloric acid was immediately added to precipitate the casein and this latter washed repeatedly by decantation, care being taken to keep it in a finely divided condition. The washed precipitate was dissolved by gradually adding portions of decinormal potassium hydroxide solution until all the casein redissolved. A milky appearing solution was so obtained which was perfectly neutral to very delicate violet litmus paper. This was filtered on a bed of filter-paper pulp and a perfectly clear filtrate obtained, which showed only a minute trace of opalescence. From this solution the casein was precipitated by hydrochloric acid, washed thoroughly by decantation with water, then with alcohol and finally dehydrated with absolute alcohol, and washed with ether. Less than nine hours elapsed from the time the milk was taken from the cow until the preparation was put under alcohol.

TABIF XXIV.-PERCFNTAGE OF LOOSELY BOLND SUlPHUR IN CASEIN. Five grams with 30 per cent. $\mathrm{NaOH}$ and $\mathrm{Pb}\left(\mathrm{C}_{2} \mathrm{H}_{3} \mathrm{O}_{2}\right)_{2}$ at 165 .

1. Chittenden and Painter: Studies from the physiol. lab. of Yale University, II, p. I56.

I Hammarsten: Ztschr.physiol. Chem., 7, 269. 
The average of these figures, $0.10 I$, shows that a very much smaller proportion of the total sulphur can be obtained from casein as sulphide than from any of the other proteins. The amount obtained agrees closely with that found by Fleitmann ;' namely, 0.07 per cent.

IV. RELATION OF TOTAL SULPHUR TO THE PROTEIN MOLECULE.

An examination of the figures obtained in determining total sulphur shows that all the proteins examined, with the exception of vicilin, phaseolin, and conglutin, contain a constant proportion of sulphur. Those proteins which can be obtained in crystals, and therefore be made quite pure, show such a uniform proportion of sulphur that there can be no doubt whatever that this is a definite constituent of their molecules. If now, as was proposed at the beginning of this paper, we calculate the simplest empirical formulas for these proteins and also for some of the other more carefully prepared and analyzed animal proteins, and multiply the figures obtained by such a whole number as shall give a molecular weight nearest to 15,000 , we shall obtain the formulas given in Table XXV. Such formulas are, of course, to be regarded as only approximate, since the methods of analysis preclude great accuracy. Carbon and nitrogen can be determined with sufficient precision to give figures falling within a few atoms of the truth, but a slight error in determining sulphur leads to serious differences in the formulas. An error of ro per cent. of the total sulphur leads to an error of about 65 atoms of carbon and 20 atoms of nitrogen. If the protein contains but 0.4 per cent. of sulphur, such an analytical error would equal 0.04 per cent. An examination of the figures obtained in determining total sulphur indicates that the average amount found for each protein is probably within 0.04 per cent. of the amount actually present. For pro. teins containing more than 0.4 per cent. of sulphur, the probable error in the formulas is correspondingly decreased, so that for those containing 0.8 per cent. of sulphur it need not much exceed 30 atoms of carbon and 10 atoms of nitrogen, and for a protein which, like ovalbumin, contains 1.6 per cent. of sulphur, the error does not amount to more than about 15 atoms of carbon and 5 atoms of nitrogen. Whether or not the proteins in fact have similar molecular weights, must remain for future investigation to show, but in the meantime the formulas given in the table seem worthy of consideration since they suggest relations not otherwise apparent.

1 Fleitmann : Loc. cil. 


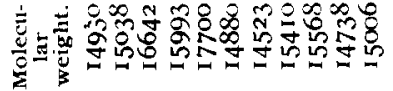

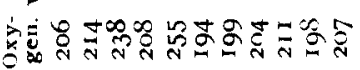

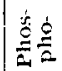

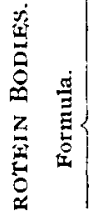

㤩

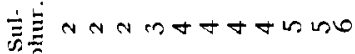

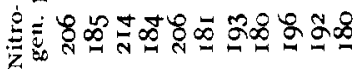

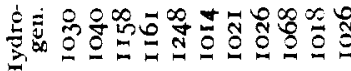
I

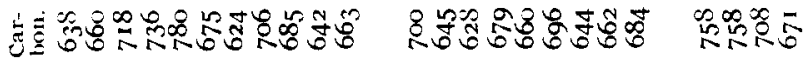

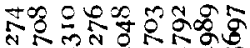

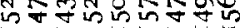

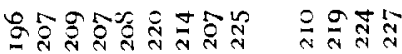

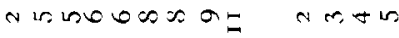

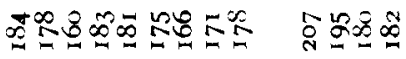

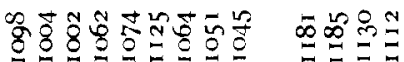

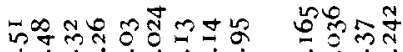

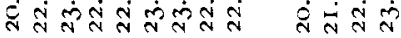

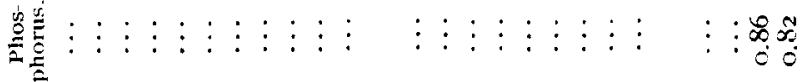

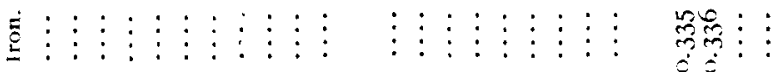

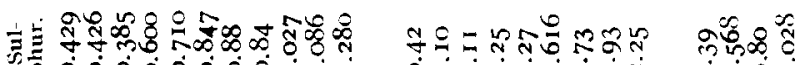
OD.

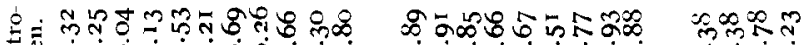

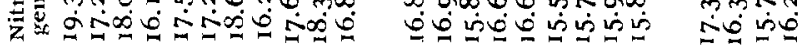

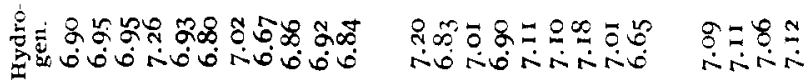

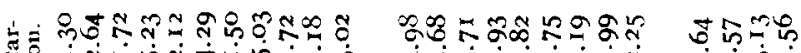

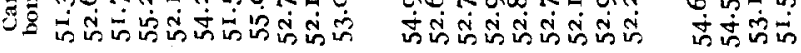

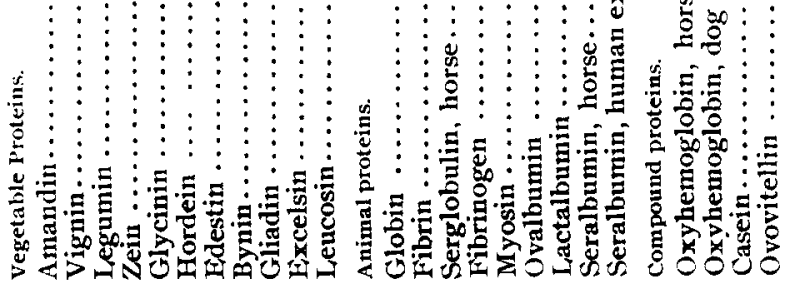


The analyses of the vegetable proteins given in the preceding table were made by the writer and his associates in this laboratory ; those of globin and serum albumin are by Schulz ; those of fibrin, ${ }^{2}$ fibrinogen, ${ }^{2}$ serum globulin, ${ }^{2}$ serum albumin, ${ }^{3}$ from human exudation are by Hammarsten; that of casein is the average of a large number of closely agreeing analyses, of many preparations, made by Hammarsten ${ }^{4}$ and by Chittenden and Painter $;^{5}$ that of myosin is the average of many closely agreeing analyses of different preparations obtained from several species of animals by Chittenden and Cummins $;^{6}$ and that of lactalbumin is by Sebelien. ${ }^{*}$

The figures given in the table for the oxyhemoglobins require explanation since it seems to be generally assumed that the composition of these bodies is still uncertain. The following analyses of oxyhemoglobin from the horse have been published:

\begin{tabular}{|c|c|c|c|c|c|}
\hline $\begin{array}{l}\text { Car- } \\
\text { bon. }\end{array}$ & $\begin{array}{l}\text { Hydro- } \\
\text { gen. }\end{array}$ & $\begin{array}{l}\text { Nitro- } \\
\text { gen. }\end{array}$ & $\begin{array}{l}\text { Sul- } \\
\text { phur. }\end{array}$ & Iron. & \\
\hline 54.87 & 6.97 & 17.31 & 0.65 & 0.47 & Hoppe-Seyler and Kossel..$^{8}$ \\
\hline 54.74 & 7.03 & I 7.28 & 0.67 & 0.45 & Otto. ${ }^{4}$ \\
\hline 54.40 & 7.20 & I $7.6 \mathrm{I}$ & 0.65 & 0.47 & Büchler..$^{10}$ \\
\hline 51.15 & 6.76 & I 7.94 & 0.39 & 0.335 & Zinoffsky. ${ }^{11}$ \\
\hline$\cdots$ & $\cdots$ & $\cdots$ & 0.44 & 0.39 & Hoppe-Seyler. ${ }^{12}$ \\
\hline 54.56 & $7 \cdot 15$ & 17.33 & 0.43 & $\ldots$ & Schulz. ${ }^{13}$ \\
\hline$\ldots$ & $\ldots$ & $\ldots$ & $\ldots$ & 0.469 & Lawrow. ${ }^{14}$ \\
\hline
\end{tabular}

In conjunction with Bunge, Zinoffsky determined iron, both gravimetrically and volumetrically, with the utmost care, using very large quantities of oxyhemoglobin, from ro to 60 grams, and making many determinations in three different preparations. None of the other analysts offer any evidence that their figures were obtained under conditions which entitle them to acceptance rather than those given by Zinoffsky. The fact that the ratio

1 Schulz: Loc, cit.

2 Hammarsten : Pflüger's Archiv., 22, 489.

3 Hammarsten: Jahresbericht.f. Thierchem., It, 19.

4 Hammarsten: Zlschr. physiol. Chem., 7, 269.

s Chittenden and Painter : "Studies from the Laboratory of Physiological Chemistry," Vol. II., p. I56.

${ }^{6}$ Chittenden and Cummins: Ibid., Vol. III, p. 156.

7 Sebelien : Ztschr. physzol. Chem., 9, 463.

8 Hoppe-Seyler : Ibid., 2, r49.

Otto, quoted by Hüfner: Ibid.. 8, 358 .

10 Biichler, quoted by Hufner: Ibid., 7, 59 .

11 Zinoffsky: Ibid., 10, I6.

${ }^{12}$ Hoppe-Seyler : "Handbuch, physiol. and pathol. chem. Analyse," I893.

${ }^{13}$ Schulz: Ztschr. physiol. Chem., 24, 469.

14 L,awrow: Ibid., 26, 343. 
between the iron and sulphur, as given by Zinoffsky, is strictly as $1: 2$, is evidence of the accuracy of his determinations, since there is every reason to believe that oxyhemoglobin is a definite compound containing hematin and protein in a molecular proportion. On the other hand, the fact that a definite ratio does not exist between the figures given by the other investigators indicates either a lack of purity in the preparations analyzed or inaccuracy of analysis.

The amount of sulphur given in these analyses differs widely. There is no evidence, however, that any of these analysts, except Zinoffsky, used unusual care in determining sulphur. Zinofisky subjected his methods for determining sulphur to a very rigid test and employed about ro grams of oxyhemoglobin, for each of six determinations. The results obtained with three different preparations fell between 0.3916 and 0.3583 . It is to be noted that the later determinations of sulphur by Hoppe-Seyler and Schulz agree with those of Zinoffsky much more closely than they do with the other earlier determinations.

All these analyses agree fairly well for carbon, hydrogen and nitrogen except that given by Zinoffsky, which differs much from the other analyses. Hiifner has suggested that this was caused by the method employed by Zinoffsky in preparing his oxyhemoglobin, but this cannot be true, because, as Jaquet points out, Zinoffsky made the preparation that he analyzed by the same method the other investigators employed. It seems more probable that the differences between Zinoffsky's figures for these elements and those of the others are analytical.

For the composition of oxyhemoglobin from the horse, I have given in the table Zinoffsky's figures for iron and sulphur, together with the average of the figures given by the other analysts for carbon, hydrogen, and nitrogen.

In conjunction with Bunge, Jaquet ${ }^{2}$ analyzed oxyhemoglobin from dog's blood and determined sulphur and iron with the same precautions and the same care that Zinoffsky used in determining these elements in oxyhemoglobin from horse blood.

But one other analysis of this substance appears to be on record, made by Hoppe-Seyler," which does not differ very widely from Jaquet's except for sulphur.

$A=$ I have been able to confirm the accuracy of Jaquet's

I Ztschr. physiol. Chem., 14, 289.

"Mea, chem. Untersuch," p. 370 . 
figures for sulphur, I have given in the table the average of them, omitting one determination of hydrogen which is manifestly too high.

V. RATIO OF LOOSELY BOUND TO TOTAL SULPHUR.

In most of the proteins examined in this investigation, as well as in those examined by others, the loosely bound sulphur is approximately a simple fraction, as the following table shows:

TABLE XXVI.-Ratio of LoOSELY Bound to Total SUlphur.

\begin{tabular}{|c|c|c|}
\hline $\begin{array}{cc} & \text { Total } \\
\text { Protein. } & \text { sulphur. }\end{array}$ & $\begin{array}{l}\text { Loosely } \\
\text { bound } \\
\text { sulphur. }\end{array}$ & $\begin{array}{l}\text { Per cent. } \\
\text { total sulph } \\
\text { as loosely } \\
\text { bound. }\end{array}$ \\
\hline Seralbumin........... $1.930^{1}$ & $1.280^{1}$ & 66) \\
\hline Oxyhemoglobin, dog $\cdots \cdots \cdot 0.5^{68^{2}}$ & 0.335 & 59 \\
\hline Serglobulin, horse....... I. I $10^{3}$ & $0.630^{1}$ & 57 \\
\hline Gliadin ............. I.027 & 0.619 & $60 j$ \\
\hline Oxyhemoglobin, horse.... $0.380^{4}$ & $0.190^{1}$ & $50 ?$ \\
\hline Vignin.............. 0.426 & 0.214 & 50 \\
\hline Amandit1,............. 0.429 & 0.217 & 50 \\
\hline Globin ............... $0.420^{1}$ & $0.200^{1}$ & 48 \\
\hline Glycinin $\ldots \ldots \ldots \ldots \ldots, 0.7$ to & 0.320 & 46 \\
\hline Vicilin .............. 0.200 & 0.092 & 46 \\
\hline Legumin $\ldots \ldots \ldots \ldots \ldots \ldots \quad 0.3^{85}$ & 0.165 & $4 I$ \\
\hline Edestin $\ldots \ldots \ldots \ldots \ldots \ldots . .680$ & 0.346 & 40 \\
\hline Zein..$\ldots \ldots \ldots \ldots \ldots .6 .600$ & 0.212 & $35)$ \\
\hline Ovovitellin ............ I.028 & 0.348 & 34 \\
\hline Fibrin $\ldots \ldots \ldots \ldots \ldots$ I. $100^{5}$ & $0.3^{80^{6}}$ & 34 \\
\hline Excelsin $\ldots \ldots \ldots \ldots \ldots \ldots$ I.086 & 0.350 & 32 \\
\hline Ovalbumin $\ldots \ldots \ldots \ldots \ldots$ I.6I 6 & 0.491 & 30 \\
\hline Phaseolin ............ 0.3 I2 & 0.072 & 23 \\
\hline Casein ................. $0.800^{7}$ & O. IOI & I3 \\
\hline
\end{tabular}

Leaving phaseolin and casein out of consideration for the present, it might be assumed that the protein molecule contain either 2 or 3 atoms of sulphur. Such an assumption presupposes, however, that in most cases the whole of the loosely bound sulphur can be converted into lead sulphide under the conditions of our experiments. The results obtained with edestin indicate plainly that one-half of its sulphur can not be thus senarated since the highest figures found fell short of one-half of the total

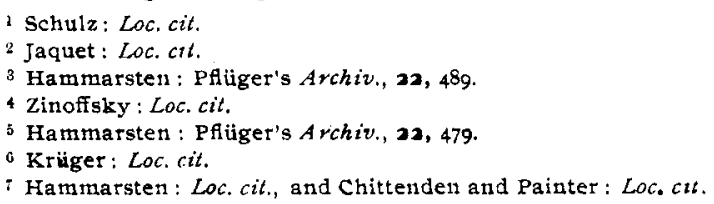


sulphur by a quantity decidedly in excess of any probable analytical error. On the other hand, nearly all fell distinctly above one-third. If this is true for edestin it may also be true for some of the other proteins: thus in excelsin the loosely boutd sulphur falls short of two-fifths of the total by nearly the same proportion that it falls short of one-half in edestin. We should, therefore, consider whether or not the proportion of loosely bound sulphur agrees with a definite number of the sulphur atoms given in Table XXV quite as well as with these simple fractions.

In the following table these proteins are given, arranged in the order of their sulphur content ; the number of atoms of fixed and loosely bound stlphur with which the results of the determinations agree most closely, assuming the number of atoms of sulphur contained in the molecule to be that shown in Table XXV, the percentage of loosely bound sulphur found in these proteins; the percentage calculated for the number of atoms of sulphur assumed to be split off; the difference between the amount found and that calculated; and the percentage of the calculated quantity that the amount found is equal to.

TABIF XXVII,-ATOMS OF IIRMI.Y AND LOOSFLY BOUND SULPHER.

\begin{tabular}{|c|c|c|c|c|c|c|c|}
\hline Protein. & 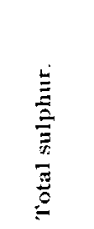 & 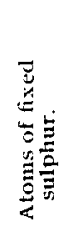 & 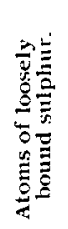 & 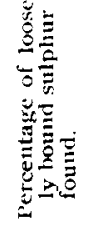 & 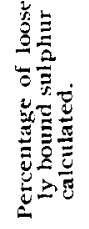 & 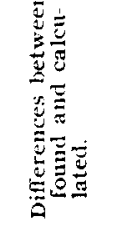 & 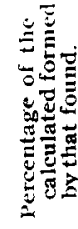 \\
\hline Legunin $\ldots \ldots \ldots \ldots$ & $0.3^{85}$ & I & I & 0.165 & 0.193 & 0.028 & \\
\hline Oxyhemoglobin, horse... & 0.390 & I & I & 0.190 & 0.195 & $\therefore 0.005$ & 97 \\
\hline Globin, horse...$\ldots \ldots$ & 0.420 & I & I & 0.200 & .210 & -0.010 & \\
\hline Vignin $\ldots \ldots \ldots \ldots \ldots$ & 0.426 & I & I & 0.214 & 0.213 & 0.001 & 100 \\
\hline Amandin...$\ldots \ldots \ldots$ & 0.429 & I & I & 0.217 & 0.213 & +0.004 & 104 \\
\hline Oxyhemoglobin, $\operatorname{dog} \ldots$ & 0.568 & 1 & 2 & 0.335 & 0.379 & -0.037 & \\
\hline 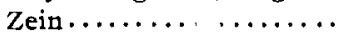 & 0.600 & 2 & I & 0.212 & 0.200 & -0.012 & 10 \\
\hline Glycinin $\ldots \ldots \ldots \ldots$ & 0.710 & 2 & 2 & 0.320 & 0.355 & -0.035 & \\
\hline Hordein $\ldots \ldots \ldots \ldots \ldots$ & 0.847 & 2 & 2 & 0.348 & 0.423 & -0.075 & \\
\hline 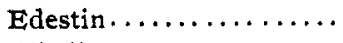 & 0.880 & 2 & 2 & 0.347 & 0.440 & -0.093 & \\
\hline 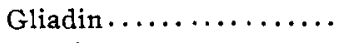 & 1.027 & 2 & 3 & 0.619 & 0.629 & --0.010 & \\
\hline Ovovitellin $\ldots \ldots \ldots \ldots$ & 1.028 & 3 & 2 & 0.348 & 0.410 & -0.062 & \\
\hline Excelsin $\ldots \ldots \ldots \ldots$ & 1.086 & 3 & 2 & 0.350 & 0.430 & -0.080 & \\
\hline Serglobulin, horse....... & I.IIO & 2 & 3 & 0.630 & 0.666 & -0.036 & \\
\hline Fibrin $\ldots \ldots \ldots \ldots \ldots$ & 1.100 & 3 & 2 & 0.380 & 0.440 & $\cdots 0.060$ & \\
\hline Ovalbumin $\ldots \ldots \ldots \ldots$ & $1.6 \mathrm{I} 6$ & 5 & 3 & $0.49 I$ & 0.609 & -0.118 & \\
\hline Seralbumin, horse ..... & I. 930 & 2 & 7 & I. 280 & 1.498 & -0.218 & \\
\hline
\end{tabular}


The amount of loosely bound sulphur found in those proteins which appear in this table as containing but one atom of such sulphur agrees almost exactly with that calculated. Of those in which a larger number of atoms appear as loosely bound, the majority show a deficiency in the amount found compared with that calculated.

Before a decision can be reached as to the proportion of loosely bound sulphur actually contained in the molecules of these different protein bodies, it is necessary to know whether all such sulphur can be obtained as lead sulphide under the conditions of the experiments described in this paper. All investigators who have undertaken to determine the proportion of loosely bound sulphur in the proteins have noted the similarity of the behavior of these substances to that of cystin under similar conditions. Cystin, however, had never been detected among the decomposition products of protein bodies until K. A. H. Moerner ${ }^{1}$ recently found it in quantity among those of horn, 6.8 per cent.; of egg membrane, 6 per cent.; of human hair, I 2.6 per cent.; and of serum albumin, over I per cent.

$\mathrm{He}$ also found in the solutions from which the cystin had been separated a not inconsiderable quantity of sulphur which, on treatment with sodium hydroxide and lead acetate, yielded lead sulphide. To what complex this latter sulphur belonged, Moerner did not determine.

Embden ${ }^{2}$ has very recently confirmed Moerner's observations by investigations undertaken independently and without a knowledge of the latter's results. Embden isolated cystin in quantity from horn and found among the products obtained from serum and egg albumin and edestin, cystein, which latter substance he considers to be the primary decomposition product of these protein bodies, the cystin being a secondary product.

From these recent observations of Moerner's and Embden's, it is highly probable that a part of the loosely bound sulphur of many protein bodies belongs either to a cystein or a cystin complex. If this is so, the results obtained in attempting to determine quantitatively the proportion of loosely bound sulphur in such proteins as contain this group must necessarily fall short of the total quantity of sulphur belonging to the cystein or cystin

1 Moerner : Ztschr. physiol. Chem, 28, 595 (1899) and Proc. 13th Inter. Cong. Med. Sec. d. Physiol., etc., p. 15, Paris, 1900.

2 Embden: Zischr, physiol. Chem, 32, 94 (Igor). 
radical, for it is well known that a part only of the sulphur of these two substances can be converted into lead sulphide by boiling with solutions of sodium hydroxide and lead acetate.

Thus Baumann and Goldmann, ${ }^{1}$ by heating cystin with io per cent. sodium hydroxide and lead acetate for nine hours, got only 68 per cent of the sulphur. Suter, ${ }^{2}$ by heating for thirty-three and one-half hours, obtained 83 per cent., and schulz," by boiling cystin with 30 per cent. sodium hydroxide, zinc, and bismuth oxide for ten hours, obtained as sulphide 53 per cent.; by boiling for twenty-five hours, 53.7 per cent.; by heating in an atmosphere of hydrogen for ten hours at $105^{\circ}-110^{\circ}, 52.4$ per cent., and by boiling cystein for ten hours, $5^{2}$ per cent. of the total sulphur contained in the substance.

In view of these facts it would seem probable that from most proteins, especially those rich in sulphur, we cannot obtain all of the loosely bound sulphur.

An examination of the figures of Table $\mathrm{XXV}$ shows that, with but three exceptions, the loosely bound sulphur obtained from those proteins which contain more than 0.43 per cent. of sulphur formed from 79 to 90 per cent. of the calculated, while the amount obtained from those containing less than 0.43 agreed with that calculated well within the limits of accuracy of analysis.

The amount of loosely bound sulphur found in all those proteins which appear in the table to contain but one atom of such sulphur agrees in every case with the calculated quantity more closely even than could be expected, while with but one exception, in all those proteins which appear as containing more than one atom of loosely bound sulphur, the quantity found is distinctly less than that calculated.

These facts may find an explanation in Moerner's observations of two sulphur-containing complexes, both of which yield lead sulphide on treating with alkaline lead solutions. It may well be that cystein or cystin is a constituent of only those proteins which are comparatively rich in sulphur, so that from these but a part of the sulphur belonging to these complexes can be obtained as sulphide, while from the others containing only the other complex observed by Moerner, all of the sulphur can be obtained. The amount of loosely bound sulphur actually found in edestin

i Baumann and Goldmann: Ztschr. physiol. Chem., 12, 25 ? (1889).

: Suter: Ibid., 20, 564 (1895).

schulz: Loc. cit. 
agrees well with such a supposition, for if I atom of sulphur belongs to a complex yielding all its sulphur as sulphide we would obtain 0.22 per cent. from this source, and if another atom belongs to cystein (Embden has obtained cystein from edestin), which according to Schulz yields about one-half its sulphur as sulphide, from this we would obtain about 0 . I I per cent., making 0.33 per cent. in all, which agrees closely with the 0.347 per cent. found. The deficiency found for most of the proteins here represented as containing more than I atom of loosely bound sulphur is nearly equal to that which would occur if these contained $\mathrm{r}$ molecule of cystein, except for serum albumin, in which the deficiency corresponds to 2 molecules of cystein or I of cystin.

In conclusion, attention should be called to casein, which presents a marked contrast to all the other proteins examined, in the fact that only one-eighth of the total sulphur was obtained as sulphide. If the complex which contains this sulphur yields all its sulphur as sulphide, the molecular weight of casein cannot be less than 30,000 ; if, on the other hand, it yields only a part of its sulphur as sulphide, it presents a marked contrast to the other protein substances which contain but little loosely bound sulphur, for these yield almost exactly one-half of their total sulphur as sulphide, which strongly indicates that all the sulphur of the complex containing this is converted into lead sulphide. Of all the proteins examined, casein yields by far the smallest proportion of loosely bound sulphur.

RESEARCH I,ABORATORY OF THE CONNECTICLT Agrictltural Experiment Station.

\title{
THE PEROXIDE CALORIMETER AS APPLIED TO EUROPEAN COALS AND PETROLEUM.
}

BY S. W. PARR.

Received Septemler 3. zgos.

\begin{abstract}
$A^{T}$ the suggestion of Dr. Lunge, the calorimeter recently deA scribed in this Journal ${ }^{1}$ has been subjected to a series of tests on European coals. The Zurich laboratory afforded especially good facilities for the work and I am indebted to $D t$. Lunge for putting them at my disposal. Much credit is also due his assistant; Mr. Offerhaus, whose very efficient help made it possi-

1 This Jourval, 22, 646 .
\end{abstract}

